\title{
Cell biology solves mysteries of reproduction
}

\author{
Peter Sutovsky
}

Published online: 4 August 2012

(C) Springer-Verlag 2012

\begin{abstract}
Reproduction and fertility have been objects of keen inquiry since the dawn of humanity. Medieval anatomists provided the first accurate depictions of the female reproductive system, and early microscopists were fascinated by the magnified sight of sperm cells. Initial successes were achieved in the in vitro fertilization of frogs and the artificial insemination of dogs. Gamete and embryo research was in the cradle of modern cell biology, providing the first evidence of the multi-cellular composition of living beings and pointing out the importance of chromosomes for heredity. In the 20th century, reproductive research paved the way for the study of the cytoskeleton, cell signaling, and the cell cycle. In the last three decades, the advent of reproductive cell biology has brought us human in vitro fertilization, animal cloning, and human and animal embryonic stem cells. It has contributed to the development of transgenesis, proteomics, genomics, and epigenetics. This Special Issue represents a sample of the various areas of reproductive biology, with emphasis on molecular and cell biological aspects. Advances in spermatology, ovarian function, fertilization, and maternal-fetal interactions are discussed within the framework of fertility and diseases such as endometriosis and diabetes.
\end{abstract}

Paleolithic fertility symbols such as the Venus of Willendorf, dating back to 24,000-22,000 $\mathrm{BC}$, indicate the great interest shown in reproduction and fertility even during the early days of humanity. Tales of early artificial insemination, e.g., thieves inseminating mares with sponges soaked with semen stolen

P. Sutovsky $(\square)$

Animal Sciences, University of Missouri-Columbia,

S141 ASRC, 920 East Campus Drive,

Columbia MO 65211-5300, USA

e-mail: SutovskyP@missouri.edu from their rivals' valuable stallions, have been passed down in Middle Eastern folklore (Foote 2002). The original Renaissance man, Leonardo Da Vinci, was a keen anatomist, leaving us detailed illustrations of dissections of female reproductive system, including a depiction of a pregnant human uterus with a fetus. In the 18th century, Lazzaro (Abé) Spallanzani, a Catholic priest with a knack for researching reproduction, fashioned tiny tubes to collect the semen of male frogs and established that physical contact between the sperm and egg is necessary for embryo development. Spallanzani used a scientific method with multiple replicates of these arguably first ever in vitro fertilization experiments; in 1784 , he performed the first successful documented artificial insemination in dogs (Pinto-Correia 1997).

Gametes are among the largest and most peculiar cells in the human or animal body, making them an ideal model system for studying a variety of cellular structures, pathways, and mechanisms. Not surprisingly, gametes were among the earliest cells to which the scientific method and tools were applied. Among the first cells ever observed under a microscope by van Leeuwenhoek and his disciple Hamm were human sperm cells. The modern hypothesis of cellular composition of multicellular bodies was introduced in 1839 by Schwann and Schleiden based in part on the observation that a complete organism develops from a single cell, namely the fertilized ovum (Aszmann 2000). In the late 19th and early 20th centuries, Theodor Boveri used sea urchin eggs and embryos to formulate the chromosome theory of inheritance (Boveri-Sutton theory). Boveri's work on the centrosome in sea urchin zygotes set the stage for the study of the cytoskeleton, a prominent area of today's field of cell biology (Baltzer 1964). The use of invertebrate and lower vertebrate gametes brought about many more advances in the modern era of cell biology. For example, the observations of calcium release in fertilized medaka eggs (Gilkey et al. 1978) ushered in cell signaling/signal 
transduction studies. Xenopus oocytes and their cytosolic extracts have been the materials of choice for the study of the cell cycle, tracing back to the ingenious experiments of Yoshio Masui (Masui and Markert 1971).

The cell biological approach to the study of reproduction has made possible important advances in medicine. The pioneering work of Edwards and Steptoe, which to date has resulted in the births of a million babies by assisted fertilization, was recently honored by the Nobel Prize. In the last two decades, reproductive biology has built on the research leading to this breakthrough and has given us human embryonic stem cells, making regenerative medicine a reality (Gearhart and Coutifaris 2011). Work on somatic cell nuclear transfer not only yielded the first cloned mammal, but also gave us information about genome reprogramming, leading to the development of induced pluripotent stem cells (Ezashi et al. 2012) and animal models of human disease (Zhao et al. 2010). Advances are being made toward the production of male and female gametes outside of the gonads, for transgenesis and the restoration of fertility in cancer and infertility patients (Dores et al. 2012). Gametes and embryos are also useful in the hot new areas of cell biology such as the study of small non-coding RNAs and epigenetics (Hossain et al. 2012). Inversely, basic developmental mechanisms such as the uniparental inheritance of mitochondrial DNA, an aspect that is important for evolutionary biology, are being explored primarily in zygotes and preimplantation embryos, as reviewed by St John (2012). The suspected link between infertility, cellular metabolism, and obesity is now being investigated by modern cell biological approaches by using mammalian embryos (Schoeller et al. 2012). Cellular signaling between mother and embryo/fetus (Geisert et al. 2012) and the embryonic origin of adult-onset disease are now better understood (Gallo et al. 2012), thereby benefitting the treatment of serious reproductive disorders such as endometriosis (Stilley et al. 2012). Further insight into female fertility can be gained from an improved understanding of folliculogenesis and ovarian function (Pohler et al. 2012; McFee et al. 2012).

Light and electron microscopy combined with organelle fractionation, proteomics, and molecular biology have provided a deeper understanding of sperm accessory structures, such as the sperm acrosome and perinuclear theca (see regular article by Ferrer et al. 2012a and review by Ferrer et al. 2012b). As reviewed by Belleannée et al. (2012), genomic and proteomic studies provide new insight into process of epididymal sperm maturation. These advances then allow the exploration of sperm function during fertilization (Ferrer et al. 2012b) and the relationship of the sperm proteome with male fertility (Govindaraju et al. 2012). Within the area of fertilization research, important advances have been made in the study of sperm-egg coat interactions including the structure and identity of sperm receptor proteins on the egg coat surface (Gupta et al. 2012) and the signaling pathways involved in sperm capacitation, a cascade of events that prepare the sperm cells within the female oviduct for fertilization (Signorelli et al. 2012). These events are mediated by ion channels that are present within the sperm plasma membrane and that are responsible for communication between the sperm cell interior and the milieu of the female reproductive system (Darszon et al. 2012). In addition to mammalian models, spermatogenesis is being researched in invertebrate and lower vertebrate systems (McClusky 2012).

The present Special Issue on Reproduction thus offers a sample of the various areas of reproductive biology, with an obvious emphasis on its molecular and cell biological aspects.

\section{References}

Aszmann OC (2000) The life and work of Theodore Schwann. J Reconstr Microsurg 16:291-295

Baltzer F (1964) Theodor Boveri. Science 144:809-815

Belleannée C, Thimon V, Sullivan R (2012) Region-specific gene expression in the epididymis. Cell Tissue Res. doi:10.1007/ s00441-012-1381-0

Darszon A, Sánchez-Cárdenas C, Orta G, Sánchez-Tusie AA, Beltrán C, López-González I, Granados-González G, Treviño CL (2012) Are TRP channels involved in sperm development and function? Cell Tissue Res. doi:10.1007/s00441-012-1397-5

Dores C, Alpaugh W, Dobrinski I (2012) From in vitro culture to in vivo models to study testis development and spermatogenesis. Cell Tissue Res. doi:10.1007/s00441-012-1457-x

Ezashi T, Telugu BPVL, Roberts RM (2012) Model systems for studying trophoblast differentiation from human pluripotent stem cells. Cell Tissue Res. doi:10.1007/s00441-012-1371-2

Ferrer M, Rodriguez H, Zara L, Yu Y, Xu W, Oko R (2012a) MMP2 and acrosin are major proteinases associated with the inner acrosomal membrane and may cooperate in sperm penetration of the zona pellucida during fertilization. Cell Tissue Res. doi:10.1007/ s00441-012-1429-1

Ferrer M, Xu W, Oko R (2012b) The composition, protein genesis and significance of the inner acrosomal membrane of eutherian sperm. Cell Tissue Res. doi:10.1007/s00441-012-1433-5

Foote RH (2002) The history of artificial insemination: selected notes and notables. J Anim Sci 80:1-10

Gallo LA, Tran M, Master JS, Moritz KM, Wlodek ME (2012) Maternal adaptations and inheritance in the transgenerational programming of adult disease. Cell Tissue Res. doi:10.1007/s00441-0121411-y

Gearhart J, Coutifaris C (2011) In vitro fertilization, the Nobel Prize, and human embryonic stem cells. Cell Stem Cell 8:12-15

Geisert R, Fazleabas A, Lucy M, Mathew D (2012) Interaction of the conceptus and endometrium to establish pregnancy in mammals: role of interleukin $1 \beta$. Cell Tissue Res. doi:10.1007/s00441-012-1356-1

Gilkey JC, Jaffe LF, Ridgway EB, Reynolds GT (1978) A free calcium wave traverses the activating egg of the medaka, Oryzias latipes. J Cell Biol 76:448-466

Govindaraju A, Dogan S, Rodriguez-Osorio N, Grant K, Kaya A, Memili E (2012) Delivering value from sperm proteomics for fertility. Cell Tissue Res. doi:10.1007/s00441-012-1452-2

Gupta SK, Bhandari B, Shrestha A, Biswal BK, Palaniappan C, Malhotra SS, Gupta N (2012) Mammalian zona pellucida glycoproteins: 
structure and function during fertilization. Cell Tissue Res. doi:10.1007/s00441-011-1319-y

Hossain MM, Sohel MMH, Schellander K, Tesfaye D (2012) Characterization and importance of microRNAs in mammalian gonadal functions. Cell Tissue Res. doi:10.1007/s00441-0121469-6

Masui Y, Markert CL (1971) Cytoplasmic control of nuclear behavior during meiotic maturation of frog oocytes. J Exp Zool 177:129-145

McClusky LM (2012) Coordination of spermatogenic processes in the testis: lessons from cystic spermatogenesis. Cell Tissue Res. doi:10.1007/s00441-011-1288-1

McFee RM, Rozell TG, Cupp AS (2012) The balance of proangiogenic and antiangiogenic VEGFA isoforms regulate follicle development. Cell Tissue Res. doi:10.1007/s00441-012-1330-y

Pinto-Correia C (1997) The Ovary of Eve. University of Chicago Press, Chicago London

Pohler KG, Geary TW, Atkins JA, Perry GA, Jinks EM, Smith MF (2012) Follicular determinants of pregnancy establishment and maintenance. Cell Tissue Res. doi:10.1007/s00441-0121386-8

Schoeller EL, Schon S, Moley KH (2012) The effects of type 1 diabetes on the hypothalamic, pituitary and testes axis. Cell Tissue Res. doi:10.1007/s00441-012-1387-7

Signorelli J, Diaz ES, Morales P (2012) Kinases, phosphatases and proteases during sperm capacitation. Cell Tissue Res. doi:10.1007/ s00441-012-1370-3

St John JC (2012) Transmission, inheritance and replication of mitochondrial DNA in mammals: implications for reproductive processes and infertility. Cell Tissue Res. doi:10.1007/s00441012-1444-2

Stilley JAW, Birt JA, Sharpe-Timms KL (2012) Cellular and molecular basis for endometriosis-associated infertility. Cell Tissue Res. doi:10.1007/s00441-011-1309-0

Zhao J, Whyte J, Prather RS (2010) Effect of epigenetic regulation during swine embryogenesis and on cloning by nuclear transfer. Cell Tissue Res 341:13-21 